Dominika Głąbińska

Uniwersytet Gdański

\section{Svenskhet som gräns}

The goal of the article "Svenskhet som gräns, Swedishness as a border" is to present problems with the concept of Swedishness from another perspective than it has been discussed in the Swedish media. The article analyses responses from Swedish political parties with regard to "Swedishness" and democracy, and it provides an insight to the contemporary situation in Sweden.

Key words: border, Swedishness, political parties, Socialdemocrats, democracy, Sweden, Swedish, traditions, politics, immigration, EU, identity, nationality, politics

Nyckelord: gräns, svenskhet, politiska partier, Sverige, svensk, traditioner, politik, EU, identitet, tillhörighet, hot mot demokratin, demokrati, brottslighet, kristendomen

\title{
Inledning
}

Denna artikel är skriven i syfte att på ett utförligare sätt försöka förklara känslorna hos en person med blandad bakgrund samt visa detta ur ett teoretiskt perspektiv med hjälp av information från politiska partier hur olika begrepp som svenskhet förhåller sig till Sverige idag samt inflika problematiken med ett multikulturellt samhälle. Mitt syfte är att framställa begreppet "svenskhet" både ur ett personligt och faktabaserat perspektiv (Mahmood 2013). Mina egna känslor är jag inte ensam om utan alla generationer i Sverige som också har föräldrar som är ickesvenska, känner igen sig i det som står skrivet nedan. Denna artikel är indelad i en analysnivå över begrepp som anses vara relaterade till svenskhet för svenskar samt en del där de politiska partierna involveras i diskussionen om vad de anser är demokrati och svenskhet baserat på deras partiprogram. För att få en bättre förståelse över vad svenskhet är kommer olika situationer betraktas ur min egen, svenska synvinkel. Detta kommer sedan att jämföras med vad som praktiskt kan kallas för "svenskt" av svaren som jag fått från de politiska partierna. Många meningar kommer att avslutas med en fråga istället för ett svar eftersom detta ämne fortfarande är någonting jag själv söker svar på. 


\section{Svenskhet}

När man har fler än en bakgrund får man ofta höra av lärare och personal i skolan samt andra svenska föräldrar att det är positivt att ha rötter från ett annat land än där man är född. När man är liten är det enda man vill att vara lik alla andra barn. I Sverige har familjer med blandade bakgrunder turen att dessa familjer inte är udda eftersom fler än en miljon barn i Sverige har föräldrar som är födda i utlandet (Migrationsverket 2016a). Det är många barn som är mörkhyade, mulatter eller som helt enkelt inte ser "typiskt" svenska ut. Låt oss tala om vad ett "typiskt" svenskt utseende betyder för en 5-åring. I den folkkära svenska författarinnans, Astrid Lindgrens, berättelser är barnen som hon talar om (inte alltid som verkliga karaktärer utan ibland påhittade eller inspirerade av barn från hennes barndom) ljus- eller rödhåriga. Det kan också klassas som en visuell del av svenskheten (Lindgren 1945). Förvisso är Pippi Långstrumps (en flicka som Lindgren hittat på) pappa lite mörk i hyn men det kan bero på att han hela livet seglat till sjöss och fått solens strålar på sig. Karlsson på taket är också han ljushyad. Likaså Pettson. Vem är det då som vi kan relatera till? Vi som inte ser ut så? För visst är det den typen barnen relaterar till som svensk? Eller är det bara jag? Kanske anser andra barn att alla i klassen, inklusive Marley som är lite mörkare, Filip som är mulatt eller Anna vars föräldrar är från Kina, är svenskar. Andra barn kanske inte såg det jag såg eller kände samma sak - en stark längtan efter att passa in - även fast jag gjorde det. För är det inte en sådan bild Sverige vill förmedla? Bilden av ett multikulturellt land och samhälle, där alla barn och vuxna får och kan se ut som de vill, där en definition på ett "svenskt" utseende inte passar in. Är det vad vi strävar efter?

Vad händer i sådana fall när vi slutar att läsa Astrid Lindgrens sagor för våra barn? Kommer det komma nya sagor där alla barn är blandade och har olika utseenden, som det ser ut i verkligheten? Hur kommer då den svenska verkligheten se ut? Att vilja passa in är inte alltid någonting fel. Det var inget beteende som var fel som jag såg upp till eller ville vara som. Jag ville helt enkelt ha en identitet som svensk, för landet jag föddes i var Sverige och därför ville jag vara svensk. Hur man än vrider och vänder på det kommer många av barnen till invandrarföräldrar någon gång i sitt liv att känna sig utanför, i landet där de föddes, i landet de kall-

lar sitt hem och där de sjunger att de vill dö. Detta moment uppstår under olika omständigheter och perioder samt situationer i ens liv. Kanske finns det personer som aldrig får en sådan känsla som jag sitter med idag, fast det tvivlar jag på. Den känslan uppstår så fort man märker att någonting annat är bättre än hemma hos sig, när landet man besöker på sommaren är någonting exotiskt, när mamma tilllagar goda rätter och pappa bjuder hem farmor från Marocko. Just då märker man att inte alla har det så, att jag och Linda inte alls har samma traditioner, att min julafton ser lite annorlunda ut än hennes, att min pappa inte firar jul alls. Då märker 
man att man i sin egen familj har traditioner som inte alls har att göra med landet man är född i. I den stunden blir det lilla fröet som man har haft inom sig, och som man har låtsats som att det inte ska växa ett stort träd av, större. Det får vatten och börjar utvecklas. Det är början på en stor konflikt, ett tyst träd som börjar växa varje gång sådana situationer uppstår där man känner att ens beteende, handlingar och traditioner inte är desamma som ens svenska vänners. Visst är vi alla olika och alla svenskar firar heller inte jul på samma sätt. Vissa är ensamma, vissa firar med sin familj. Dock finns det saker som svenskar inte gör eller heller inte kan tänka sig att göra under juletiden, som vi gör, jag och hundratals andra svenska medborgare. Vi firar jul och alla andra högtider så som vi har blivit lärda hemifrån, vi med föräldrar som inte kommer från Sverige, som tog med oss våra traditioner och fröet som nu växer starkt inom oss, barn till invandrare.

Det finns ingenting som är rätt eller fel. Det är känslor vi talar om och dessa går inte att bedöma utifrån ett så enkelt perspektiv som vi gör nu. Vi kan inte sätta ord på känslor och det ska vi heller inte göra, enbart om vi verkligen är säkra på vad vi känner. Varför säger jag vi? Jag som talar om mina två identiteter, kanske tre, vem vet? Du som läsare försöker förstå min inre konflikt som har följt mig och funderar på om det är värt att läsa vidare. Om du har en gnutta oro eller en liten fundering och kanske ändå inte riktigt vet, vem DU är, är detta till dig. Låt oss gå tillbaka till Sverige, det komplicerade men ändå så enkla landet. Enkelt eftersom nästan allt går att lösa. Det finns svar på allt. Vi behöver inte ens tänka utan staten gör det åt oss. Komplicerat för att vi är människor, och människor har känslor, som någon dag kommer komma ut. Vi började denna artikel med att tala om identitet och vad har vi kommit fram till? Att det är svårt att ha dubbla identiteter. Du förstår kanske inte, du som är född i ett land och har föräldrar från samma land. Du har en sådan tur, att du vet vem du är, att du har en stämpel som du kan identifiera dig med. Du vet nog vem du ska kämpa för, vem du ska dö för, om så blir fallet. Om du själv vill det eller ej är det ditt eget val, om du älskar ditt land eller inte. Vad gör vi andra, vad gör jag? Vad gör alla unga människor som aldrig har bott i sina föräldrars hemländer men som älskar dem lika mycket som Sverige, eftersom de har varit där på sommaren. Eftersom de har kusiner som de spenderar somrarna med, för att maten är god, för att överallt är det mer fritt än hemma i Sverige. För att alla därhemma kan ha roligt och skratta även utan barnbidrag eller bostadsrätt på Östermalm. Sedan kommer vi hem igen, till Sverige där kompisarna väntar, de riktiga vännerna som finns där genom allt som händer, genom skolgången där mamma vill att du ska bli civilingenjör eftersom både pappa, morbror och din bror redan är det, där vi blivit kära i fel person och inte kan vara tillsammans för att vi är från olika kulturer. De vännerna är svenska, de är som du. Svenska enligt lag. Det är de du kommer hem till efter sommaren i Iran eller Kuba. I hemlandet var du en turist men du känner ju till språket. Du känner dig hjälplös i ditt hemland. 
Du känner ingen där förutom familjen, du kan inte röra dig fritt fast allt är tillåtet. Du har redan byggt upp en svensk identitet, att vissa saker bör man helt enkelt inte göra. De passar inte. Hemma i Sverige är du stabil. Vad är bäst då? För man måste ju välja, någon gång måste man välja sida. Eller går det att leva med att ha båda länderna i sitt hjärta lika mycket? Går det att kriga för både Sverige och Danmark? Går det när just de två länderna krigar med varandra? Så klart att det inte går. Så klart att man måste välja. Och hur gör man då? Hur vet man, var man hör hemma?

Länder som Sverige börjar gå ifrån sina rötter och traditioner och gör det samtidigt möjligt för nya att ta plats. Ju fler människor från utlandet som bosätter sig i Sverige, desto mer anpassar landet sig till människorna som bor där. Man kan antingen vara för dessa ändringar eller emot dem. Man kan också tycka att människor som väljer eller är tvungna att flytta till ett land borde anpassa sig till lagarna, värderingarna och traditionerna som finns där eller att dessa lagar, värderingar och traditioner ska anpassa sig till människorna i landet. De flesta skulle väl säga att det är någonting bra att Sverige anpassar sig till sin befolkning. Det är svårt att föreställa sig att en person som har två nationaliteter, två eller tre pass, påstår att man inte ska låta nya traditioner ta över, att man skall stänga gränserna för folk som inte har samma traditioner som en själv, när man själv har uppfostrats i traditioner som inte representerar landet man kämpar för. Det är svårt att rättfärdiga de känslorna. Det svaret försöker jag hitta, i allt jag gör, dagligen. Det är en lång väg framför mig och alla andra barn till invandrare som varje gång någon på skoj frågar vilket lag vi hellre skulle vilja se vinna när det är en fotbollsmatch mellan lag som representerar våra två ursprungsländer. För dem är det en rolig fråga och ett svar som inte kommer att ändra någonting i deras liv. Svaret ändrar dock något hos oss. Antingen vattnar det det lilla trädet inom oss eller ej. De flesta människor kan medge att om vi uttalar ord eller meningar högt blir de meddetsamma mer realistiska. Just därför har jag slutat att svara på den frågan. Jag säger istället att jag inte vet, för det gör jag inte heller. Jag vet inte, vilket land jag skulle vilja se vinna. Eller jag kanske gör det men är rädd för reaktionerna jag skulle få.

Just nu bor jag inte i mitt hemland. Jag bor en timme bort med flyg, i landet där min mamma är född, och jag kunde inte må bättre. Jag känner att jag har lärt mig mycket om livet och mig själv samtidigt med flytten från Sverige. Hur kommer det sig dock att mina viktigaste verk handlar om och kommer att handla om en längtan som jag så fort kan bota? Den längtan är efter mitt hemland men inte så som det är just nu. Det är inte det landet jag lämnade. Kanske är det för mitt egoistiska jag bättre att Sverige förändras till det sämre eftersom jag har en ursäkt att inte åka hem.

Varje gång någon frågar mig om jag saknar Sverige känns det som att allt går sönder inom mig och jag avhåller mig från att visa det. Jag och min bästa vän som jag har känt i snart 20 år flyttade till Polen samtidigt, för exakt fem år sedan. I början 
var allt nytt och vi visste inte hur vi skulle hantera vår hemlängtan. Bara att ses påminde oss om vårt hemland. Vi sa till varandra att vi inte får tänka på Sverige för då kommer vi aldrig klara våra studier och alla mål som vi satt. $\mathrm{Nu}$, sex år senare, är jag färdigutbildad men vill inte sluta studera så jag har börjat forska istället. Min bästa vän är klar med sin läkarutbildning och har flyttat tillbaka till Sverige. Varför gör inte jag det, frågar alla. För detta är mitt liv nu, här. Det är så många saker som jag älskar med att bo här i Polen samtidigt som det får mig att bli orolig för framtiden.

Barn och uppfostran - det är två saker som jämnt och ständigt snurrar i huvudet på många som är i samma situation som jag. Man behöver inte bo utomlands för att ha en inre konflikt med sig själv om hur man ska uppfostra sina barn. Mina barn kommer förmodligen inte få en svensk uppfostran till hundra procent av olika anledningar. En av mina högsta drömmar är att mina barn ska känna sig svenska, ska känna en tillhörighet. Varför just svenska vet jag inte, antagligen för att det är så jag känner mig, svensk, men ändå inte. Att vara svensk är, enligt mig, att känna tillhörighet. Så pass stark är denna känsla. Det är så jag definierar mig, mitt beteende, min personlighet, allt jag älskar och allt jag vet. Sverige.

Året är 2017. Sverige nu och då. En stor förändring av det land som bland annat mina föräldrar invandrade till. Jag är säker på att många invandrare, som kom till Sverige på 70-talet kan säga att det har ändrats, och tyvärr till det sämre. Det är svårare att få jobb, brottsligheten har ökat, det finns ett mindre antal lägenheter på marknaden, större segregation bland utlandsfödda och svenskar osv. De flesta ser inte något problem med att leva i det system de själva byggt upp, med partierna de själva röstat fram. Tvärtom är de glada och nöjda med tillvaron. Eller så är de helt enkelt så ovetande om de val de har gjort att de inte ser vad som händer, hur alla andra länder ser på Sverige och rynkar på näsan och talar om Sveriges guldperiod i dåtid. Vad gör vi alla? Vad gör jag själv? Jag sitter i ett land som jag inte känner tillhörighet till, tar bara det bästa från det jag kan. Jag vet inte hur jag ska kämpa, för ett land där många inte anser mig som polack, där jag själv inte känner mig polsk, där jag inte förstår mig på den polska mentaliteten och vissa typer av beteenden förvirrar mig något hemskt. Vad gör jag själv för Sverige, för landet som jag säger att jag älskar så mycket? Jag skriver, försöker ta reda på vem jag är, medan allt börjar gå åt fel håll, medan mitt land färdas i en riktning jag inte känner igen. Vad gör du för ditt land? Förhoppningsvis mer än jag.

I nästa del vill jag lägga vikten på hur svenskhet och demokrati visas inom kommunikationen i den svenska politiken. Detta är, enligt min åsikt, oerhört viktigt eftersom politiken som man praktiserar i ett land återspeglar samhället och dess normer. Svenskhet är en del av ett otroligt stort fenomen som debatteras i Sverige just nu och demokratin är en självklar del utav det landet. Ibland kan man undra om det är Sverige som man talar om i definitionen av demokrati eller tvärtom. Varför jag har valt att ta upp ämnet demokrati i denna artikel är eftersom 
jag personligen anser att på grund av fenomenet "svenskhet" kan det uppstå en krock mellan dessa idéer. Demokratin i Sverige har under en längre tid varit väldigt stabil och en stark förebild för övriga länder i världen att ta efter. Dessvärre är jag nog helt säker på att denna bild sakta men säkert börjar förstöras på grund av olika faktorer som tvingar fram det värsta inom detta politiska system. Vad svenskhet är, är ännu idag oklart även om media försiktigt börjar tala om detta ämne och böcker som "Jakten på svenskheten" av Qaisar Mahmood, börjar skrivas. Det jag vill få fram är att även om detta ämne börjar diskuteras, är det på något sätt fortfarande tabubelagt eftersom Sverige alltid har varit betraktat som ett land där alla är svenskar och där svenska myndigheter inte skiljer på hudfärg och ras. Detta är punkten då allting börjar vända men samtidigt vill de svenska politikerna bevara bilden av det Sverige som alla en gång kände till. Av den anledningen tog jag mig an att ta reda på vad de olika politiska partierna anser att definitionen på demokrati och svenskhet är. Sambandet mellan den tidigare avhandlingen av en mer personlig syn på identitet och den hos politiska partier är att visa hur pass de politiska partierna och deras program fortfarande är noga med att välja sina ord kring ett ämne som just nu diskuteras vilt i media. Enligt min åsikt borde svaren vara ännu tydligare och på något vis skapa en ståndpunkt $\mathrm{i}$ ämnet $\mathrm{i}$ fråga. Om inte politikerna är villiga att tala om problematiken gällande bland annat multikulturalism och massinvandring kommer media inte heller att göra det och då lägger man över ansvaret på befolkningen som är så pass styrd av välfärdsstaten och kontrollerad av myndigheterna att ett klart och framförallt självständigt val och yttrande kommer bli svårt att göra.

\section{Socialdemokraterna}

Socialdemokraterna har en väldigt lång historia som började år 1889 då partiet bildades i Sverige (Socialdemokraterna 2017). Det var det partiet som var allra störst och är det än idag, i antal medlemmar och förut i antal röster. Socialdemokraternas ideologi kan man säga är en del av det Sverige som vi idag lever i. Den livskvalitet och alla de bra och mindre lyckade sakerna i dagens samhälle kan vi säga är ett långvarigt resultat av de socialdemokratiska regeringarna. Sverige har under många generationer varit en förebild för de resterande Europeiska länderna. Dess godhet som erbjuds i form av olika sorters bidrag, stipendier, välfärd, trygghet, tolerans, jämlikhet och till en stor del frihet är väldigt exemplarisk i hela världen. Allt detta har i sin takt utvecklats med just de ledande socialdemokratiska partierna i Sverige. Om vi ska fördjupa oss i begreppet demokrati så beskriver socialdemokraterna sin syn på det på ett väldigt öppet sätt. Eftersom partiet redan från första början hade ett sådant tankesätt, märker man att definitionen enligt 
dem är mycket utvecklad. Den står för allt som har med partiet att göra. Socialdemokraterna vill framför allt forma ett samhälle som är grundat i de demokratiska tankarna och värderingarna. Eftersom de är det parti som utvecklat demokratin och eftersom den är grunden till partiets existens, måste den finnas i alla deras handlingar, normer och bestämmelser.

För Socialdemokraterna är frihet och solidaritet bland människor målet för deras lyckade politik. Socialdemokraterna anser att människor ska ha all makt i samhället eftersom de tillsammans bildar det. Alla som bor i ett och samma samhälle ska ha rätten att bestämma eftersom det är vad demokrati står för. Varken pengar eller andra faktorer ska hindra demokratin från att utvecklas. Socialdemokraterna strävar efter ett samhälle där varje individ ska ha en betydande roll vad gäller ekonomi, samhällsfrågor och utveckling i landet. Demokratin ska helt enkelt finnas överallt där människan finns (Socialdemokraterna 2016). Socialdemokraterna anser dock att deras politik gentemot ett idealiskt demokratiskt samhälle hela tiden måste utvecklas och stärkas. Partisekreterare Carin Jämtin och riksdagsledamot Leif Jakobsson anser att det system vi har idag är under hot och har varit det sedan början på 2000-talet då högerextrema rörelser runt om i Europa började utvecklas och bli allt mer uppmärksammade. Enligt Jämtin och Jakobsson är den stärkta islamofobin, antisemitismen, den negativa utsattheten av kvinnor, personer med olika sexuella läggningar samt invandrare ett hot mot demokratin vi har idag (Arbetarnas Bildningsförbund 2016). Socialdemokraterna har inte en egen kategori eller punkt i sitt program där de talar om identitet som ett enskilt begrepp. Identitet nämns under titeln „Kultur för ett levande Sverige”. Där ligger fokus på att tala om hur kultur kan få människor att skapa ett band i samhället som man lever i och hur man kan lära sig att uttrycka sina känslor genom kultur. I samma veva sägs det också att kultur inte bara ger människor drömmar utan också lär dem att skapa sig en identitet. Man förklarar inte begreppet identitet som sådant mer än att det vore någonting man skulle kunna sträva efter (Socialdemokraterna odaterat c). I en dokumentär vid namn "Kampen om identiteten" som gjordes av SVT (Sveriges Television) år 2014, talar olika politiker inom Socialdemokraterna om på vilket sätt partiet har förlorat sin identitet och vad som måste göras för att den ska återuppbyggas. Socialdemokraternas förra partiledare, Mona Sahlin, talar öppet om sina hopplösa resultat i det senaste valet samtidigt som hon säger att det inte är en fråga som rör om man ska bygga upp partiet utan hur. Med det sagt kan man dra slutsatsen att partiet inte har en enskild punkt som handlar om något slags identitet utan det ordet uppstår i olika sammanhang. I artikeln sägs det att socialdemokraterna genomgår en väldigt stor kris just nu och att de borde leta efter väljare hos utbildade vänsterväljare och minoritetsgrupper. Enligt artikeln skulle de kunna lockas av den identitetspolitik som andra partier satsar allt mer på, där kön och olika grupper lyfts fram (Appleblom 2016). 
Inom minoritetsgrupper kan människor vara väldigt måna om sin identitet eftersom själva idén om att höra till en grupp grundar sig i att alla känner tillhörighet. Om flera representativa grupper i samhället skulle få för sig att rösta på socialdemokraterna skulle de kunna få ett nytt slags identitetskänsla som parti. Partiet har nästan alltid stått för väldigt stora frågor och idéer som drivit dem framåt. $\mathrm{Nu}$ under de senaste åren har mindre grupper i samhället blivit allt mer representativa och borde betraktas på allvar, som potentiella väljare. Det som också är värt att lyfta fram är att partiet inte nämner någonting om begreppet "svenskhet". Kanske är det så att de vill ta avstånd från att kategorisera grupper och människor av rädsla för att någon ska känna sig utstött. Enligt Socialdemokraterna är alla människor lika värda, oavsett härkomst, nationalitet eller sexuell läggning. Detta kan också vara ett skäl till att de inte vill uttala sig om vad svenskhet betyder enligt dem.

\section{Vänsterpartiet}

Det som fångar ens blick direkt efter att ha öppnat Vänsterpartiets hemsida, är att begreppet demokrati tar väldigt liten plats där. I en av punkterna i partiprogrammet finns titeln "En demokratisk uppfattning" som kort beskriver hur Vänsterpartiet ser på det utövade demokratiska systemet i Sverige och nämner vad som måste förbättras. Partiet anser att den politiska makten i ett samhälle ska utövas av riksdagen, som ett resultat av allmänna, fria och rättvisa val där man fördelar mandaterna proportionellt mellan partierna. Regeringen har skyldighet att vara ansvarig inför riksdagen. Partiet listar vilka som, enligt dem, är de viktigaste grenarna inom demokrati. Det är: föreningsfriheten, offentlighetsprincipen, meddelarfriheten och yttrande- och tryckfriheten. De fortsätter med att säga att med den långvariga kampen mot kungar och överklass har människor tillkämpat sig den ovärderliga rätten till en organiserad opposition, allmänna debatter, granskning av politiker och rätten till demonstrationer, förändring och protester bl.a. massmedia (Västerpartiet 2016). Sedan nämns olika former av diskriminering i samhället på grund av kön, sexuell läggning, hudfärg, ålder, religion osv. som borde tas på största allvar. Vänsterpartiet menar att utan ett samhälle där rättigheter och lagar spelar en betydande roll, kan demokratin ifrågasättas och de samhällsgrupper och den starkares rätt blir lag. Olika förändringar i samhället ska framläggas av regeringen men samtidigt beviljas av folket genom val och särskilda folkomröstningar så som referendum. Monarkin borde bytas ut mot ett republikanskt styrelsesätt. Religionsfriheten borde granskas, enligt Vänsterpartiet. Staten ska vara religiöst neutral och institutioner så som den Svenska Kyrkan ska lösas upp (Ibid.).

Det första som man lägger märke till är att det finns så lite information just om själva demokratin. Mycket information är i form av en skeptisk inställning, som 
ovan. Det som skulle kunna ifrågasättas är upplösningen av den Svenska Kyrkan som vänstern skulle vilja genomföra. Å ena sidan nämner de att demokratin i Sverige kan vara i form av en folkomröstning, så ifall det skulle komma fram i en folkomröstning att större delen av samhället vill ha kvar denna myndighet, vad skulle då hända? Skulle deras önskan, (om partiet hade en bestämmande roll i riksdagen) bestå eller skulle man då avgöra beslutet genom resultatet från folkomröstningen? I sådana fall kan man tycka att partiet säger emot sig själva (Vänsterpartiet odaterat). Det som kan vara intressant att nämna är att Vänsterpartiet är ett av de mest EU-kritiska partierna i Sverige. Trots folkomröstningen år 1994, som slutligen resulterade i att Sverige gick med i EU, stod Vänsterpartiet fortfarande fast vid sin åsikt om att Sverige inte borde vara medlem. Enligt dem, är EU ett hot mot demokratin genom att unionen med olika krav och villkor, begränsar sina medlemmar. Vänsterpartiet är emot bilden av idén om ett superrike med gemensam försvarsmakt och utrikespolitik.

Fortsättningsvis är det mycket lite information som kan tas upp vad gäller identitet och begreppet svenskhet. Om svenskhet finns det ingenting att finna i partiets program. Om identitet talar man i tredje person. Man talar inte om en identitet som partiet innehar utan om att vänstern "måste skaffa sig en identitet" (Sveriges Radio 2011). Det som sägs är att Vänsterpartiet under en lång tid har identifierat sig med Socialdemokraterna och deras politik och därmed alltid kommit lite i skymundan. De måste därför se till att ta mer ansvar över sin och Sveriges politik för att skaffa sig en egen, separat identitet.

\section{Liberalerna (tidigare Folkpartiet liberalerna)}

Liberalerna värderar demokrati väldigt högt då man kan se att i deras partiprogram framställs demokratin inom många olika punkter. De tar upp att Sverige inte borde sälja vapen till diktaturer, att Sveriges utrikespolitik ska vara demokratisk mot andra nationer och man talar mycket om mänskliga rättigheter. Demokrati enligt Liberalerna utgår från frihet och att makten tillhör människorna. De anser att demokrati är grunden till allt som står för deras politik (Liberlerna odaterat). Om man jämför med vad och hur mycket andra partier skriver om demokrati så har Liberalerna ganska lite information om sina åsikter när det gäller just den punkten. Man kan säga att den helt enkelt är mer inriktad på kvalitet än kvantitet. Inom själva partiprogrammet finns det inte punkter som identitet eller svenskhet. Liberalerna har själva genomgått en transformation som ocksä är väldigt synlig. Den 22 november år 2015 bytte partiet namn från Folkpartiet liberalerna till enbart Liberalerna, detta på grund av att partiet anser att deras politik är mer liberal och de själva tycker att det namnet beskriver dem och deras väljare bättre. De säger 
också att på grund av den högerextrema vågen i Europa vill de ha en tydlig politik som arbetar mot detta. Namnet är helt enkelt starkare och tydligare än Folkpartiet liberalerna (eller enbart Folkpartiet som de hette i början) (Brandel 2015). Här kan vi också tydligt se att det inom själva partiet har funnits en identitetskris som har lett till dessa förändringar.

\section{Fortsättning på föregående kapitel}

I detta kapitel kommer jag att ta upp resterande partier som jag har valt att inkludera i min uppsats. Det kommer att vara Moderaterna, Kristdemokraterna och Sverigedemokraterna. Jag har valt att göra denna placering eftersom de sista tre partierna har mer gemensamt med varandra än de som jag presenterade tidigare. Moderaterna, Kristdemokraterna och Sverigedemokraterna är alla tre inställda på ett mer traditionellt sätt än de föregående partierna. Det de partierna har gemensamt är skattesänkningar, frågor som rör invandring, äldreomsorg samt en mer traditionell inställning till religion, nationalitet och landets intressen. Tidigare nämnda partier tar givetvis också upp denna problematik och dessa frågor men de sistnämnda gör det på ett tydligare sätt och för vissa av partierna brukar de nämnda frågorna vara deras utgångspunkter. Namnbytet gjordes således för att förtydliga partiets liberala identitet (Mellin 2015).

\section{Moderaterna}

I sitt partiprogram beskriver Moderaterna att de arbetar för en levande demokrati som ska vara tydlig i alla aspekter av samhället. Människors lika värde och allas rättigheter är värden som moderaterna värderar högt. Man skall kunna tala om sina åsikter och utbyta åsikter med varandra på ett respektfullt sätt. Tolerans och öppenhet är enligt Moderaterna nyckeln till ett välfungerande samhälle där alla människor är inkluderade (Moderaterna odaterat). Moderaterna vill arbeta på att beslut som politiker tar ska förflyttas från dem, till medborgarna så att varje människa känner att hen kan styra över sitt eget liv. Moderaterna vill att alla ska kunna ha insyn i den statliga verksamheten så att människor ska vara måna om hur allting fungerar. Moderaterna anser också att förtroendet mellan medborgare och stat är otroligt viktigt för en fungerande demokrati.

När det kommer till identitet har Moderaterna själva genomgått en större identitetskris som delvis fortfarande håller i sig. Moderaterna har från början setts som ett alternativ till de borgerliga partierna, lite som ett parti för överklassen. Deras omvandling till att bli ett parti för alla medborgare är inte det lättaste när man 
under lång tid har haft en viss stämpel som man nu vill bli av med. Moderaterna har nästan blivit tvungna att gå ifrån trenden om överklassen efter Socialdemokraternas vinst i valet år 2014. De var partiet som skulle representera alla andra medborgare som inte röstade på det vinnande partiet och de som var osäkra på vilket parti de skulle lägga sin röst på. Detta ansvar tog Nya Moderaterna på sig med partiledare Anna Kinberg Batra och sedan dess har de försökt att på ett milt sätt bli ett parti som fungerar för alla svenskar men också med sina egna åsikter (Westerlind 2015). Moderaterna har fått kritik för att deras åsikter ibland kan förväxlas med Sverigedemokraternas, någonting som de inte vill förknippas med.

När det gäller svenskhet har Moderaterna varit riktigt nära att stärka allting som har med detta begrepp att göra. Det har varit ett krav från partiets ungdomsförbund (Karaveli 2002). På partiets hemsida ser vi inga referenser till eller punkter om identitet eller om svenskhet som sådan. Med det kan vi enbart konstatera att partiet inte vill associera sig med dessa frågor och att de tydligen inte är tillräckligt relevanta eller viktiga att ta upp. Inför valet 2010 deltog Moderaterna i en debatt om svenskhet och nationalism. Debatten handlade om ett svenskkontrakt som går ut på att invandrare måste intyga att de känner till svenska värderingar och Sveriges lagar. De talade om hur svårt människor från utlandet har att integreras i det svenska samhället och att det har uppstått ett "vi" och "de"-problem. För dessa uttalanden blev de påhoppade av Gudrun Schyman som anser att Moderaterna blivit påverkade av Sverigedemokraternas politik, vilket till viss del kan stämma, enligt dessa uttalanden (Holmén och Karlsson 2009). Det som tydligt framstår i politiken som Moderaterna utövar är att de klart och tydligt vill hålla sig borta från allting som segregerar människor. Man kan konstatera att de själva känner till att sådana frågor finns och att det kanske vore bra att diskutera dem men just nu är de alldeles för färska och laddade med en extrem "högerkänsla", och därför vill de undvika att ta upp dessa frågor. Det går dock inte att avgöra huruvida Moderaterna i framtiden kommer börja tala mer öppet om svenskhet och identitet. Allt beror på hur situationen i Sverige kommer att se ut och om behovet av att diskutera dessa frågor fortfarande kommer att vara aktuellt.

\section{Kristdemokraterna}

På Kristdemokraternas hemsida kan vi hitta information om vad de anser att demokrati står för. Det som är intressant är att det är väldigt lite information om denna punkt men samtidigt tar de upp yttrande-, press- och rörelsefrihet som några av de självklara rättigheterna inom ett demokratiskt samhälle, någonting som jag inte lagt märke till hos de flesta partierna. Kristdemokraterna skriver att alla element, även de tidigare nämnda måste finnas med i ett samhälle för att vi ska kunna tala 
om det som en demokrati. De tar också upp hur viktigt det är med lika rättigheter oavsett kön, etnicitet, religion och tillhörighet (Kristdemokraternas odaterat). Även fast man inte hittar mycket information om själva definitionen av demokrati enligt Kristdemokraterna kan vi hitta en förklaring som är kort men konkret. Den visar oss också att demokrati utan de ovan nämnda punkterna inte fungerar. De flesta partierna koncentrerar sig på att beskriva vad som faktiskt är demokratiskt och glömmer ibland att nämna viktiga punkter som utgör själva systemet. I likhet med föregående partier har Kristdemokraterna inte några punkter om identitet eller svenskhet i sitt program. På Kristdemokraternas hemsida i Järfälla finns det en liten beskrivning om traditioner och identitet där det står att varje land har sina traditioner och sin identitet som är intressant för människor och om någon gör att t.ex. ett luciatåg inte får hållas i kyrkan slätar vi ut vår identitet, vilket gör Sverige mindre intressant för alla de som vill lära känna Sverige och dess kultur (Kristdemokraterna 2012). Kristdemokraterna tar inte upp frågan om identitet som sådan utan det talas om en kris inom själva partiet som har med åsikter kring homosexualitet att göra. Många av KD:s väljare är kristna och värderar den kristna tron högt. Många har också olika uppfattningar kring att homosexuella ska få adoptera barn, Prideparaden och könsidentitet i sig. Det kan säkerligen ha splittrat människorna inom själva partiet. Som varje år hålls Prideparaden och (nästan) alla partimedlemmar och partier är välkomna att vara med. Hos Kristdemokraterna har vissa avstått att gå eftersom det funnits plakat med t.ex. "Fuck your God" på, en text som kan diskriminera många medlemmar. Detta år har dock partiledare Ebba Busch Thor officiellt sagt att hon kommer att vara med på Prideparaden för att visa sitt stöd för alla människor (Grönlund 2016). Redan efter att hon gått ut med det på sociala medier har hon fått mycket kritik av sina väljare för att inte stå för det partiet egentligen borde stå för, dvs. kristna värderingar som går emot de värderingar som Prideparaden står för.

Dessa värderingar kan vi också analysera på olika sätt eftersom det inom kristendomen finns en konflikt om att tillåta homosexuella par att gifta sig och en pågående debatt t.ex. i Polen, där majoriteten av befolkningen är kristna men många unga anser att b.la. homosexuella borde kunna adoptera barn. År 2010 tog KD upp ett förslag om en kurs i svenskhet för invandrare. Detta förslag kritiserades starkt och det började spekuleras i om KD i och med detta försökte få tillbaka sina "förlorade" väljare som övergått till Sverigedemokraterna men Michael Arnefur, som är hjärnan bakom förslaget, säger att så är inte fallet. Invandrare är en stor del av det svenska samhället idag och man talar mycket om vad olika partier kan göra för att integrationspolitiken ska utvecklas. Kristdemokraterna anser att en introduktionsutbildning i svenska värderingar bara skulle gynna de som kommer till Sverige medan de som är kritiskt inställda till förslaget anser att detta är något som man lär sig på SFI (Svenska för invandare) (SVT 2010). 


\section{Sverigedemokraterna}

Sverigedemokraterna vill införa mer direktdemokrati dvs. att människor ska ha ännu fler möjligheter till att lokalt, kommunalt och regionalt kunna genomföra omröstningar som kommer att gynna dem. Sverigedemokraterna anser att demokrati kan vara mycket svår att upprätthålla i ett samhälle som bebos av många olika kulturer eftersom alla människor har olika intressen och behov. De använder också språkargumentet och menar att om vi i Sverige tala olika språk kan det vara svårt att komma fram till en konsensus som kommer att gynna alla medborgare (Sverigedemokraterna odaterat a). Sverigedemokraterna önskar att se en gemensam kulturell identitet som också är nationellt homogen. Sverigedemokraterna tar inte upp "svenskhet" eller "identitet" som egna begrepp i sitt program, dock finns det många uttalanden och åsikter om dessa begrepp som har gjort partiet känt för att vara mer extrema i sina åsikter än andra partier. För det första är Sverigedemokraterna inställda på en välfungerande invandringspolitik och en förminskning av själva invandringen till Sverige. De har många gånger gått ut med att det inte gynnar staten att invandrare kommer till Sverige i den mån de gör och att man först och främst borde ta hand om de som redan kommit och nu bor i Sverige (Sverigedemokraterna odaterat b). Allt detta har lett till att man har börjat gå djupare in på vad partiet egentligen står för och om själva invandringen kan vara ett hot mot det. Sverigedemokraterna anser att invandrare är ett hot inom många områden. För det första anser de att för mycket av statens pengar går åt till invandring och biståndet som de har rätt till. Partiet vill sänka biståndsmålet till $0,7 \%$ av BNP (bruttonationalprodukten), vilket enligt dem ska leda till att man sparar upp till 10 miljarder kronor per år. Partiet uttrycker också att invandrare från muslimska länder kan vara ett hot mot demokratin i Sverige samt mot politiken som vi strävar efter (Borås Tidning 2010). Under fliken "Kulturpolitik" kan vi hitta en text med titeln „Partiet för kulturarvet” där det står att Sverigedemokraterna värnar om Sveriges traditioner och kulturarv. De beskriver att nya traditioner, seder och normer som inte är svenska mycket väl kan bli det om själva processen sker på ett naturligt och frivilligt sätt.

I den svenska kulturen inkluderar de allt som någonsin skrivits, sagts, skapats, gjorts eller tänkts av personer som tillhör den svenska nationen (Sverigedemokraterna odaterat d). I principprogrammet använder SD inte uttrycket „svenskhet”. Detta är dock vad som står i texten om Sverigedemokraterna och Nationen: „Som infödd svensk räknar vi den som är född eller i tidig ålder adopterad till Sverige av svensktalande föräldrar med svensk eller nordisk identitet. Som assimilerad till den svenska nationen räknar vi den med icke-svensk bakgrund som talar flytande svenska, uppfattar sig själv som svensk, lever i enlighet med den svenska kulturen, ser den svenska historien som sin egen och känner större lojalitet med den svenska än med någon annan nation" (Sverigedemokraterna odaterat e). 
Problemet med ett sådant uttalande är att vi egentligen inte vet vem som faktiskt är svensk eftersom den motsatta informationen inte finns dvs. vem som inte är svensk. Man kan tänka sig att om en person bara uppfyller vissa punkter så är denne inte svensk - enligt Sverigedemokraterna. Att ens ta upp en sådan problematik har under flera års tid varit ett mycket kontroversiellt ämne i Sverige men börjar nu mer och mer diskuteras, på grund av den kraftiga flyktingkrisen i Europa. SD är det parti som högst och mest talat om dessa punkter. Det har också lett till enorm kritik från alla andra partier samt de flesta medborgare i Sverige.

\section{Reflektioner}

Som vi ser finns det inga konkreta svar från de ovannämnda politiska partierna på det vi kallar för "svenskhet" även fast detta ämne just nu är mycket aktuellt i Sverige. Vi kan ställa oss frågan varför det är så viktigt att hitta en definition på vad svenskhet innebär. Oftast brukar man definiera ett ord om en specifik situation kräver det. För partiet Sverigedemokraterna kan svenskheten vara hotad av invandrare, flyktingar och allmänt utlandsfödda. Flyktingkrisen som drabbade hela Europa, inte minst Sverige som tog emot ca 160 tusen människor på flykt, kan sätta sina spår i samhället och svenskar kan börja känna sig osäkra av många olika anledningar (Migrationsverket 2016b). Kriterierna för svenskhet är oklara just därför att en klar definition inte existerar. Enligt min åsikt är politiker i Sverige rädda för att sätta en konkret definition gällande denna terminologi eftersom människor då kommer att hamna i olika fack, beroende på deras ursprung. Detta är allt som Sverige och dess befolkning har kämpat för att undvika i tiotals år, att skapa ett segregerat samhälle där alla personer betraktas som olika och där man sätter stämplar. Problemet är att det redan sker i Sverige. Människor sätts redan i fack och många invandrare känner sig utanför i samhället. Det verkar som om integrationspolitiken i Sverige egentligen är en fasad som till viss del fungerat men som i längden och med det antal invandrare som bosatt sig i Sverige inte längre fungerar. Många områden i Sverige, speciellt i storstäderna, är utsatta och arbetslösheten, brottsligheten samt fattigdomen bara ökar där (Byström 2014). En annan reflektion man då kan göra är, vad är felet med att vi alla ser olika ut i samhällets ögon? Borde det inte vara precis det vi strävar efter i Sverige, att alla människor är olika men har lika värde. I artikeln kan man ställa sig frågan vilken svensk vi egentligen talar om. Vem är hen? Är det den svensken som är självständig så fort hen flyttar hemifrån eller skaffar sig sitt första jobb? Vad händer när vi försöker bestämma om våra barn ska börja på förskolan eller inte? Är det egentligen vi svenskar som bestämmer över oss själva eller gör staten det i en sådan utsträckning och på ett sådant sätt att vi själva inte längre förstår hur lite makt och kontroll vi 
har över våra liv? Identitet utan gräns. Svenskhet utan gräns. Detta kan komma att rädda eller förstöra Sverige.

\section{Källor}

Litteraturförteckning

Lindgren, A. (1945). Boken om Pippi Långstrump. Stockholm: förl. Rabén och Sjögren.

Universitetsforskning

Głąbińska, D. (2016). Vem är svensk? Det globala hotet mot demokrati och hur det förhåller sig till identitet. Magisteruppsats, Gdańsk: Gdańsk Universitet.

Internetkällor

Appleblom, R. (2016). Ledare: Det är kärvt för Socialdemokraterna. Västmanlands Läns Tidning, 26 januari 2016, http://vlt.se/asikt/ledare/1.3488963-ledare-det-ar-karvt-forsocialdemokraterna (läst: den 10 mars 2017).

Arbetarnas Bildningsförbund. (2010). Utveckla demokratin, 24 augusti 2016, http://www.abf. se/Distrikt-och-avdelningar/ABF-Skane/ABF-Malmo/Om-ABF/Ideprogram/Utveckla-demokratin/ (läst: den 10.03.2017).

Borås Tidning. (2010). SD ser invandring som ett hot, 3 september 2010, http://www.bt.se/valet/ sd-ser-invandring-som-ett-hot/ (läst: den 10.03.2017).

Brandel, T. (2015). Klart: Folkpartiet heter nu Liberalerna. SVD, 22 november 2015, http:// www.svd.se/direktrapport-nu-forsvinner-folkpartiet (läst: den 10.03.2017).

Byström, M. (2014). Var femte ung i förorten utan jobb. Svenska Dagbladet, 5 mai 2014, https:// www.svd.se/var-femte-ung-i-fororten-utan-jobb (läst: 6.09.2017).

Grönlund, E. (2016). Busch Thor i Pride får KD-profiler att se rött. SVT, 25 juni 2016, http://www.svt.se/nyheter/inrikes/busch-thor-i-pride-far-kd-profiler-att-se-rott (läst: den 10.03.2017).

Holmén, C. och K.J. Karlsson. (2009). Fredrik Reinfeldt om svenskhet och nationalism. Expressen, 18 september 2009, http://www.expressen.se/nyheter/val-2010/fredrik-reinfeldt-om-svenskhet-och-nationalism/ (läst: den 10.03.2017).

Karaveli, M. (2002). Svensk identitet viktigt. SVD, 25 augusti 2002, http://www.svd.se/svensk-identitet-viktig (läst: den 10.03.2017).

Kristdemokraterna. (2012). Vad betyder tradition och identitet?, Kristdemokraternas partiprogram, Järfälla, http://wp.kristdemokraterna.se/jarfalla/vad-betyder-tradition-och-identitet/ (läst: den 27.06.2016).

Kristdemokraterna. (odaterat). Demokrati, Kristdemokraternas partiprogram, https://www.kristdemokraterna.se/VarPolitik/Korta-Svar-AO/\#D (läst: den 27.06.2016).

Liberlerna. (odaterat). Demokrati, Liberlernas partiprogram, https://www.liberalerna.se/politik/demokrati/ (läst: den 27.06.2016).

Mahmood, Q. (2013). En svenskhet för alla i tiobudord. Svenska Dagbladet, https://www.svd.se/ en-svenskhet-for-alla-i-tio-budord (läst: den 4 juli 2013). 
Mellin, L. (2015). Folkpartiet byter namn - men hur nya blir de egentligen? Aftonbladet, 21 november 2015, http://www.aftonbladet.se/nyheter/kolumnister/lenamellin/article21806648. ab (läst: den 10.03.2017).

Migrationsverket. (2016a). Befolkningstillväxt, https://www.migrationsinfo.se/befolkning/befolkningstillvaxt/ (läst: den 2.03.2017).

Migrationsverket. (2016b). Nästan 163000 människor sökte asyl i Sverige 2015, 1 januari 2016, https://www.migrationsverket.se/Om-Migrationsverket/Nyhetsarkiv/Nyhetsarkiv2016/2016-01-01-Nastan-163-000-manniskor-sokte-asyl-i-Sverige-2015.html (läst: den 10.03.2017).

Moderaterna. (odaterat). Demokrati, Moderaternas partiprogram, http://www.moderat.se/demokrati (läst: den 27.06.2016).

Socialdemokraterna. (2016). Vad är socialdemokrati, http://www.socialdemokraterna.se/Webben-for-alla/Arbetarekommuner/Sotenas/Var-politik1/Vad-ar-socialdemokrati/ (läst: den 27.06.2016).

Socialdemokraterna. (2017). Vår historia, Vårt parti, http://www.socialdemokraterna.se/Vart-parti/Var-historia/ (läst: den 10.03.2017).

Sverigedemokraterna (odeterat a) A-Ö, Sverigedemokraternas partiprogram, https://sd.se/var-politik/var-politik-a-till-o/ (läst: den 27.06.2016).

Sverigedemokraterna. (odaterat b). Invandringspolitik, Sverigedemokraternas partiprogram, https://sd.se/var-politik/invandringspolitik/ (läst: den 27.06.2016).

Sverigedemokraterna. (odaterat c). Kultur, Socialdemokraternas partiprogram, http://www.socialdemokraterna.se/Var-politik/Var-politik-A-till-O/Kultur/ (läst: den 27.06.2016).

Sverigedemokraterna. (odaterat d). Kulturpolitik, Sverigedemokraternas partiprogram, https:// sd.se/var-politik/kulturpolitik/ (läst: den 27.06.2016).

Sverigedemokraterna. (odaterat e). Principprogrammet, Sverigedemokraternas partiprogram, https://sd.se/wp-content/uploads/2013/08/principprogrammet2014_webb.pdf (läst: den 27.06.2016).

Sveriges Radio. (2011). Vänsterpartiet måste skaffa sig egen identitet, 8 december 2011, http:// sverigesradio.se/sida/artikel.aspx?programid=83\&artikel=4846319 (läst: den 10.03.2017).

SVT. (2010). KD-förslag om kurs i svenskhet kritiseras, 10 februari 2010, http://www.svt.se/nyheter/lokalt/skane/kd-forslag-om-kurs-i-svenskhet-kritiseras (läst: den 10.03.2017).

Vänsterpartiet. (2016).Västerpartiets partiprogram, https://www.vansterpartiet.se/material/partiprogram (läst: den 27.06.2016).

Vänsterpartiet. (odaterat). Vänsterpertiet är ett EU-kritiskt parti, Vänsterpartiet i EU-parlamentet, http://eu.vansterpartiet.se/vad-tycker-vi-2/vansterpartiet-ett-eu-kritiskt-parti/ (läst: den 10.03.2017).

Westerlind, L. (2015). Nya Moderaterna har en identitetskris. Folkbladet, 16 april 2015, http:// www.folkbladet.nu/1467857/nya-moderaterna-har-en-identitetskris (läst: den 10.03.2017). 